Б. В. Ободоева. Философское воззрение буддийского учения о теории цвета в тибетских трактатах XV-XVIII веков

УДК 316.4

DOI: 10.18101/1994-0866-2019-2-31-35

\title{
ФИЛОСОФСКОЕ ВОЗЗРЕНИЕ БУДДИЙСКОГО УЧЕНИЯ О ТЕОРИИ ЦВЕТА В ТИБЕТСКИХ ТРАКТАТАХ ХV-XVIII ВЕКОВ
}

\author{
(C) Ободоева Баярма Владимировна \\ аспирант отдела философии, \\ культурологии и религиоведения, \\ Институт монголоведения, буддологии и тибетологии СО РАН \\ Россия, 670047, г. Улан-Удэ, ул. Сахьяновой, 8 \\ E-mail: bayarma19@gmail.com
}

Статья посвящена анализу основных тибетских трактатов по иконометрии, описывающих философское обоснование цвета в канонической буддийской живописи танка. Внимание уделяется основным отличительным особенностям в трактовке взаимодействия цвета и его связей с философской составляющей буддийского учения. В изучении теоретического осмысления буддийской живописи рассматривается традиционная система описания цвета и его взаимодействий. Эта система была связана с духовной практикой, которая отразилась в религиозной живописи тибетского народа, и результатом явилась насыщенная и многообразная палитра буддийского иконописца. В изучении тибетской живописи сформировалось несколько теорий относительно взаимоотношений основных цветов. В тибетской религиозной живописи в описании цвета отражается философское воззрение «метода» и «мудрости», где «мудрость» символизирует материнское, женское начало, а «метод» - отцовское, мужское начало. Определённая художественная терминология, относящаяся к обозначению цвета, является уникальным наследием тибетского искусства, в котором посредством цвета отражается философское воззрение буддийского учения, берущего свое начало с древних традиций Индии.

Ключевые слова: буддийская философия; метод; мудрость; танка; тибетская живопись; цвет; Тибет; традиция.

Для цитирования:

Ободоева Б. В. Философское воззрение буддийского учения о теории цвета в тибетских трактатах XV-XVIII веков // Вестник Бурятского государственного университета. Философия. 2019. Вып. 2. С. 31-35.

Введение. Буддийское искусство в системе религиозно-философского образования в Тибете входит в состав «пяти высших областей наук» (rig gnas che ba lnga) и относится к разделу «искусство» (bzo rig ba), куда входят скульптура, аппликация и художественная живопись. В свою очередь, изобразительное искусство состоит из настенной живописи дэбри (sdeb-ri) и свитковой живописи танка. В разделе тибетской живописи танка присутствует сложившаяся терминология, основанная на древних практиках и соотносящаяся с философией метода и мудрости. Эта теория упоминается в канонических текстах, описанных в XV-XVIII вв.

Для оценки существующей ситуации в области изучения буддийской тибетской живописи как философской системы традиционного образования следует провести обзор исторических источников по тибетской живописи XV-XVIII вв. Фундаментальные исследования тибетской живописи провел американский тибетолог Дэвид Джексон, большая часть которых приводится в книге D. P. Jackson, 
J. A. Jackson «Tibetan Thangka Painting: Methods and Materials» [9, c. 202]. В отечественном источниковедении исследование К. М. Герасимовой «Памятники эстетической мысли Востока. Тибетский канон пропорций. Трактаты по иконометрии и композиции Амдо XVII в.» [1, с. 303] до сих пор является самым востребованным и актуальным в изучении буддийского искусства. В дополнение к уже опубликованным источникам мы представляем к рассмотрению и изучению рукопись XVIII в., составленную тибетским философом Дильмар геше Тэнзин Пунтсоком (Dilmar Geshe Tendzin Phuntshog) (Dil-mar dge-bshes Bstan-'dzinphun-tshogs «Kun gsal tshon gyi las rim me tog mdangs ster ' $\mathrm{ja}$ ' 'od 'bum 'dyin zhes day ba bzhugs pa'I gzigs phyogs legs so»), работу тибетского ученого, профессора Пекинского университета и художника современности Тенпа Рабдэна (Bstan pa rab brtan) «Bod kyi ri mo'I slob deb lag len zhun thigs zhes by aba bzhugs so» [13, p. 355]. Старинная рукопись Дильмар геше (Dil-mar dge-bshes Bstan-'dzin- phuntshogs) является уникальным памятником древности, написана старинным тибетским языком и сложна для восприятия, большой раздел посвящен технике изготовления красок, философии живописи и теории цвета. Произведение тибетского профессора Тенпа Рабдэна достаточно ясно изложено и имеет много общего с древним трактатом Dil-mar dge-bshes Bstan- 'dzin- phun-tshogs. Этот текст нельзя считать комментарием к тексту Дильмар геше.

Самая ранняя теория цвета была описана ученым XV в. Bo-dong Pan-chen [12, p. 254], где он опирается только на пять основных цветов: белый, красный, синий, желтый, черный. Это самый ранний источник, сохранившийся на протяжении веков среди тибетских трактатов по теории цвета.

Другая, более обширная теория цвета, основанная на трактатах знаменитых мастеров Sum-pa mkhan-po [16, p. 356], Rong-tha [17, p. 215], Mi-pham-rgya-mtsho [15, p. 89. 6-90.1] и Blo-bzang-bstan-rgyan-mtshan [1, p. 115], пользовалась большой популярностью в Бурятии, Монголии и среди тибетских художников, в частности. C переводом трактата Blo-bzang-bstan-rgyan-mtshan на русский язык можно ознакомиться в исследовании К. М. Герасимовой «Памятники эстетической мысли Востока. Тибетский канон пропорций. Трактаты по иконометрии и композиции Амдо XVII в.» [1, с. 115-247]. Философский аспект по теории цвета относительно первых трех источников состоит из восьми основных цветов: семи «отцовских» и одного «материнского». К отцовским цветам относятся синий, зеленый, красный, оранжевый, желтый и два дополнительных цвета для обводки - индиго (rams) и бордово-красный лаковый краситель (skag), к материнскому цвету - только белый. Остальные производные цвета появляются за счет смешивания одного «материнского» и семи «отцовских» цветов. Исходные цвета называются сыновьями (bu) и в общей сложности их насчитывается четырнадцать [16, p. $389 ; 15$, p. 88].

В соответствии с трактатами Sum-pa mkhan-po, Rong-tha и Mi-pham-rgya$\mathrm{mtsho}$ многообразная палитра цветов получается в результате смешивания «отцовских» и «материнского» цветов.

В теории цвета тибетской живописи танка отражается философское воззрение буддийского учения, основанное на взаимодействии «отцовских» и «материнского» цветов. Подобная теория «метода» и «мудрости» присутствует в буддийской философии, где «мудрость» символизирует материнское, женское начало, а «метод» - отцовское, мужское. Значимые философские аспекты мы проведем по 
Б. В. Ободоева. Философское воззрение буддийского учения о теории цвета в тибетских трактатах XV-XVIII веков

тексту досточтимого ламы Цонкапы «Три основных аспекта пути» [3, с. 1437]. Главной мотивацией учения Будды было достижение окончательного счастья просветления. Оно достигается при обязательном выполнении двух условий: практики бодхичитты (устремленности к просветлению ради блага всех живых существ) и истинного философского воззрения. Эти два условия обозначаются терминами «метод» и «мудрость». Метод олицетворяет бодхичитту или устремленность к просветлению ради блага всех живых существ; мудрость - это истинное воззрение о пустотности всех феноменов бытия. Эти два основных условия достижения просветления подобны двум крыльям, с помощью которых устремляются высоко в небеса, и позволяют достичь «Всеведения Будды». Мудрость, постигающая пустоту, должна быть подкреплением устремленности, которая является подкреплением мудрости. Если нет метода, но есть мудрость, постигающая пустоту, будет только освобождение для себя и не будет возможности достижения «Всеведения Будды». Если нет метода, то практика не будет путем, ведущим к просветлению. Без мудрости, постигающей пустоту, имея только бодхичитту, будет возможность заботиться о других живых существах, но не будет возможности избавиться от своих изъянов. Так же и в живописи отражаются философская взаимосвязь цветов и их взаимодействие между собой.

Но в отличие от предыдущих трех трактатов в рукописи Dil-mar dge-bshes Bstan-'dzin- phun-tshogs и в исследовании Bstan pa rab brtan материнские и отцовские цвета даже не упоминаются. Многообразная палитра оттенков получается в результате смешивания «коренных» (rtsa ba) и «второстепенных» (yan lag) цветов. К восьми коренным цветам относятся белый, желтый, синий, зеленый, красный, черный и еще два дополнительных цвета - оранжевый и бурый. Второстепенные цвета получаются в результате смешивания восьми «коренных» цветов и в тексте их точное количество не обозначено. Но отдельной главой присутствует терминологический список с названиями всех основных цветов художественной палитры тибетской живописи.

В этом исследовании мы частично приведем основные термины цветовой палитры буддийского иконописца. Например, при смешении «отцовского» синего и «материнского» белого цвета образуется «сын» - голубой оттенок (sngo skya). И если в исходный цвет добавить дополнительно белый цвет, то получится светло-голубой (sngo se). При смешении «отцовского» зеленого и «материнского» белого образуется светло-зелёный цвет (ljang skya). И если в исходный цвет добавить дополнительно белый цвет, то получится бледно-зеленый оттенок (ljang $\mathrm{se).} \mathrm{При} \mathrm{смешении} \mathrm{зеленого,} \mathrm{желтого} \mathrm{и} \mathrm{белого} \mathrm{оттенка} \mathrm{получается} \mathrm{светло-}$ зеленый с желтым оттенком (ljang-ser). После смешения оранжевого оттенка с белым получается светло-оранжевый (li skya). Из смешения желтого оттенка и оранжевого получается оранжевый с желтым оттенком (li ser) и т. д.

Кроме того, только в двух трактатах Mi-Pham-rgyamtso (1846-1912) [15, p. 89.6-90.1] и Sumpa Mkhanpo (1704-1788) [16, p. 356] упоминаются дополнительные два цвета: «старшие сестры» — чайный цвет (ja kha) и дымчатый (dud kha), a также «слуга» - смесь киновари и чернил. В других трактатах такое разнообразие взаимоотношении цветов не встречается. Только в этих трактатах упоминается, что при смешении бордово-красного лакового красителя (skag) с белым цветом получается цвет «легких» (glo kha), а также цвет «печени» (mchin kha), который получается за счет смешивания белого и индиго (rams) [9, с. 92]. По 
названию этих цветов можно определить, что они использовались при написании медицинских танка для Атласа тибетской медицины. В большинстве случаев современные тибетские художники не смешивают с белым пигментом индиго (rams) и бордово-красный лаковый краситель (skag).

В исследовании американского тибетолога David P. and Janice A. Jackson [9, p. 92] отмечается, что одним из лучших является трактат Rong-tha, где наиболее подробно описаны теории цветов и их сочетания. Его описание особенно ценно, потому что помогает установить значение более редких терминов, которые встречаются в других текстах по буддийскому искусству и философском обосновании буддийской живописи.

Трактат Dil-mar dge-bshes Bstan-'dzin- phun-tshogs «Kun gsal tshon gyi las rim me tog mdangs ster 'ja' 'od 'bum 'dyin zhes day ba bzhugs pa'I gzigs phyogs legs so», по нашему мнению, является более детальным, несмотря на то, что есть много повторяющихся моментов в описании терминологий основных и второстепенных цветов, присутствуют дополнительные сведения, относящиеся к материалам и технической стороне изготовления красок. Но в отличие от других трактатов автор заостряет внимание на философском аспекте буддийской живописи.

Заключение. Среди буддийских иконописцев сложился определенный язык художественной терминологии, относящийся к обозначению цвета. За каждым оттенком цвета закреплен определенный термин, понятный художникам танкописцам. Благодаря такой традиционной терминологической системе можно безошибочно определить точность цвета, его яркость и глубину. Все это свидетельствует о том, что древние танкописцы познавали палитру цветов не интуитивно, а посредством обучения по каноническим, философским трактатам в рамках традиции своей школы.

Каждый мастер танкописи сам смешивает цветовую палитру, опираясь на традиции своей школы и коренные трактаты. В этом заключается уникальность буддийской живописи, берущей свое начало с древних традиций Индии и Тибета, где посредством цвета отражается философское воззрение буддийского учения, основанное на взаимодействии«отцовских» и «материнского» цветов.

Литература

1. Герасимова К. М. Памятники эстетической мысли Востока. Тибетский канон пропорций. Трактаты по иконометрии и композиции Амдо XVII в. Улан-Удэ: Бурят. кн. изд-во, 1971. 303 с.

2. Герасимова К. М. Вопросы методологии исследования культуры Центральной Азии. Улан-Удэ: Изд-во БНЦ СО РАН, 2006. 338 с.

3. Чже Цонкапа «Большое руководство к этапам Пути Пробуждения» / пер. А. Кугявичюса; под ред. А. А. Терентьева. СПб.: Нартанг, 2010. 5 т. 1437 с.

4. Рерих Ю. Н. Тибетская живопись; пер. с англ. А. Л. Барковой. М.: Международный Центр Рерихов, 2002.216 с.

5. Терентьев А. А. Определитель буддийских изображений. СПб.: Нартанг, 2004. $304 \mathrm{c}$.

6. Chandra L. Dictionary of Buddhist Iconography: 15 vol. New Delhi, 1999-2005. Vol. $1-15.1336 \mathrm{p}$.

7. David P. Jackson and Janice A. Jackson // Shambhala Publications, Inc. Boulder. Colorado. 80306-0271. $1984.183 \mathrm{p}$.

8. Dagyab L. S. Tibetan Religious Art. Wiesbaden, 1977. 173 p. 
9. Jackson D. P., Jackson J. A. Tibetan Thangka Painting: Methods and Materials. Jackson. L.: Serindia Publications, 1984. 202 p.

10. Jackson D. A History of Tibetan Painting: the great Tibetan painters and their traditions. Vienna: Verlag der Österreichischen Akademie der Wissenschaften, 1996. 456 p.

11. Je Tsong kha pa. The Great Treatise on the Stages of the Path to Enlightenment: The Lamrim Chenmo. Vol. 1-3, transl. by Lamrim Chenmo Translation Committee / ed. by W. C. Joshua. Cutler - Snow Lion Publications, 2000. Vol. 1. 434 p.; 2002. Vol. 2. 304 p.; 2004. Vol. 3. 295 p.

12. Bo-dong, Mkhaspa, (1375-1451) New Delhi, Tibet House, 1969. Vol. 2. P. 254.4.-255.3.

13. Bstan pa rab brtan. Bod kyi ri mo'I slob deb lag len zhun thigs zhes by aba bzhugs so. China, Beijing. 2006. 355 p.

14. Council for Tibetan Education, Reader 9. Dharamsala. 1967. 258 p.

15. Mi-Pham-rgyamtso (1846-1912). Bzognas nyer mkho za ma tog, Collected Writings, Gangtok, Sonam Topgay Kazi.Vol. 9. P. 89.6-90.1

16. Sumpa Mkhanpo, (1704-1788). New Delhi, 1975. Vol. 4. P. 353-402.

17. Rong-tha Blo-bsang-dam-chos-rgya-mtsho (1863-1917). Thig gi lag len du ma gsal bar bshad pa bzo rig mdzes pa'I kha rgyan, New Delhi, Byams-pa-chos-rgyal, n.d. 215 p.

18. Tucci G. Tibetan painted scrolls: 3 vol. Roma: La libreria dello stato, 1949. Vol. 1-3.

\title{
PHILOSOPHICAL VISION OF THE BUDDHIST THEORY OF COLOR IN TIBETAN TREATISES OF THE $15^{\text {th }}-18^{\text {th }}$ CENTURIES
}

\author{
Bayarma V. Obodoeva \\ Research Assistant, \\ Institute for Mongolian, Buddhist and Tibetan Studies SB RAS \\ 8 Sakhyanovoy St., Ulan-Ude 670047, Russia \\ E-mail: bayarma19@gmail.com
}

The article is devoted to the analysis of the main Tibetan treatises on iconography, describing the philosophical substantiation of color in canonical Buddhist thangka painting. We have paid special attention to the main distinctive features in the interpretation of color interaction and its relationship with the philosophical component of Buddhist teachings. While studying Buddhist painting we considered the traditional system of colors description and their interactions. This system is associated with spiritual practice, which was reflected in the religious painting of the Tibetan people, and resulted in a rich and diverse palette of Buddhist thangka painters.

In Tibetan religious painting the description of color reflects the philosophical consideration of "method" and "wisdom", where "wisdom" symbolizes the maternal, feminine principle, and "method" - the fatherly, male principle. Certain artistic terminology relating to the designation of color is a unique legacy of Tibetan art, in which the philosophical outlook of Buddhist doctrine originating from the ancient traditions of India is represented through color.

Keywords: Buddhist philosophy; method; wisdom; thangka; Tibetan painting; color; Tibet; tradition. 